\title{
Rekonsiliasi sebagai Paradigma Misi Trinitarian Inkarnasional dan Konstruksinya pada Ruang Publik
}

\author{
Donald Steven Keryapi \\ Sekolah Tinggi Teologi Paulus, Medan \\ stevendonal@sttpaulusmedan.ac.id
}

\begin{abstract}
This study aims to reveal how the concept of Missio Dei as reconciliation in the trinityinacrnational mission paradigm and construct the form of mission Dei as reconciliation in the public sphere. The research method used is a qualitative research method through the Literature Research approach whose research results are obtained through reading various literatures on the mission and practice of reconciliation. This research reveals that Missio Dei is a mission carried out by the Triune God so that humans can reunite in the fellowship of the Triune God through reconciliation through the incarnation of the Word, namely Jesus Christ. Missio Dei as this reconciliation forms the format of the mission as reconciliation between individuals/groups based on the trinitarianincarnational framework and is constructed through a construction circle approach that starts with open relationships and ends with risky actions. The conclusion is that mission Dei as reconciliation is an alternative in the context of today's mission.
\end{abstract}

Keywords: mission; missio dei; public sphere; reconciliation; trinitarian-incarnational

\begin{abstract}
Abstrak: Penelitian ini bertujuan untuk mengungkapkan bagaimana konsep Missio Dei sebagai rekonsiliasi dalam paradigma misi trinitas-inakrnasional dan mengkonstruksikan bentuk mission $D e i$ sebagai rekonsiliasi dalam ruang publik. Metode penelitian yang dipakai ialah metode penelitian kualitatif melalui pendekatan literatur research yang hasil penelitiannya didapat melalui pembacaan berbagai literatur tentang misi dan praktik rekonsiliasi. Penelitian ini mengungkapakan bahwa Missio Dei adalah misi yang dilakukan oleh Alah Tritunggal agar manusia dapat bersekutu kembali dalam persekutuan Allah Tritunggal melalui rekonsiliasi yang dilakukan melalui inkarnasi sang Firman yaitu Yesus Kristus. Missio Dei sebagai rekonsiliasi ini membentuk format misi sebagai rekonsiliasi antar setiap pribadi/kelompok berdasarkan kerangka trinitarian-inkarnasional dan dikonstruksikan melalalui pendekatan lingkaran konstruksi yang dimulai dari hubungan terbuka yang diakhiri dengan tindakan beresiko. Kesimpulan yang didapat ialah bahwa missio Dei sebagai rekonsiliasi merupakan alternatif dalam konteks misi masa kini.
\end{abstract}

Kata kunci: misi; missio dei; rekonsiliasi; ruang publik; trinitarian-inkarnasional

\section{PENDAHULUAN}

Karya ini didasari bahwa Rekonsiliasi merupakan sebuah paradigma Misi Trinitarian Inkarnasional yang relevan bagi Indonesia sebagai konteks Missio Dei. Konsep Missio Dei merujuk kepada tindakan Allah di dalam dan melalui inkarnasi. Hal ini dipahami bahwa Inkarnasi Firman Allah dalam diri Yesus Kristus dimaknai sebagai tindakan Allah yang memasuki keberadaan manusia dengan segala konsekuensinya. Hal ini juga dimaknai sebagai bagian dari rekonsiliasi Allah kepada manusia. Gereja (umat Allah) sebagai pengemban misi Allah harus terus menerus mengaktualkan misi rekonsiliasi Allah tersebut 
melampaui segala sekat-sekat suku, agama, ras, golongan. Dengan demikian, maka "rekonsiliasi" dalam tulisan ini menjadi kata kunci sebagai bagian dari misi inkarnasional Allah Tritunggal.

Seringkali misi dipahami secara sempit, secara salvic, atau dengan kata lain misi hanya dipahami sebagai sebuah usaha untuk menyelamatkan jiwa-jiwa dengan cara mengonversi (menobatkan) mereka. Hal ini dapat dipahami sebagai akibat dari bentuk tafsir teks Alkitab, misalnya Matius 28: 19-20; Markus 16:15; Kisah Para Rasul 1: 8. Selain itu, pemahaman juga merupakan akibat dari pandangan teologis tentang kedatangan Kristus kembali yang dapat dipercepat jika penginjilan kepada makhluk tuntas diselesaikan oleh orang beriman. ${ }^{1}$ Misi Kristen seperti yang telah dikatakan sebagai tindakan Allah di dalam dan melalui Inkarnasi, sehingga umatnya dapat berpartisipasi aktif bagi dan untuk dunia. David Bosch menegaskan pula bahwa misi yang demikian merupakan dimensi yang luas dan utuh yang mencakup berbagai aspek seperti witness, service, justice, healing, reconciliation, peace, evangelism, fellowship, church growth, contextualiization. ${ }^{2}$ Selain itu dalam beberapa konferensi Misi dijelaskan bahwa Misi Kristen bersifat terpadu yang memadukan dan mengintegrasikan beberapa bentuk yaitu penginjilan, pelayanan, tindakan sosial, seperti diakoni, rekonsiliasi konflik secara bersamaan. ${ }^{3}$

Misi trinitarian sesungguhnya menempatkan Trinitas sebagai pusat pemikiran teologis tentang misi. teologi trinitarian pada perspektif ini menunjuk kepada sifat komunal dan radikal dari Allah yang mengalir dari Allah secara melimpah dan bermuara kepada penarikan umat manusia kepada persekutuan Allah tritunggal, dan oleh sebab itu maka kekristenan mengakui model persekutuan antara Bapa, Anak dan Roh Kudus merupakan sebuah model relasi bagi identitas personal dan merengkuh keberagaman dalam komunitas dan berguna bagi praksis kehidupan Kristen.

Artikel ini hendak menjawab setidaknya beberapa pertanyaan, tentang bagaimana konsep Missio Dei bentuk paradigma misi trinitarian-inkarnasional, dan bagaimana konstruksi dan model misio Dei sebagai rekonsiliasi dalam konteks ruang publik khususnya masyarakat kristen Indonesia. Hal ini penting karena melihat bahwa Indonesia merupakan konteks publik bagi masyarakat Kristen yang bersifat majemuk dan selalu berisiko dalam pertemuan-pertemuan silang antar suku, agama, ras, dan antar golongan. Selain itu dari pertanyaan di atas bertujuan untuk menemukan konstruksi Missio Dei sebagai bentuk rekonsiliasi tersebut bagi kepentingan misi Kristen di Indonesia. Penelitian tentang rekonsiliasi sebagai paradigma misi trinitarian-inkarnasional ini unik karena menggali keberadaan misi sebagai bagian dati tindakan Allah Tritunggal yang merengkuh keberagaman dalam komunitas yang berbeda dan selalu mendamba rekonsiliasi. sebelumnya penelitianpenelitian tentang misi hanya bersifat di sekitar perbincangan mengenai metode. Penelitian tersebut dilakukan oleh David Thang Moe yang berjudul Themes and Methologies in Pauline

\footnotetext{
${ }^{1}$ Arie de Kuiper, Missiologia (Jakarta: BPK Gunung Mulia, 1996), 9

${ }^{2}$ David J. Bosch, Transforming Mission: Paradigm Shift in Theology of Mission (Maryknoll: Orbis, 1991), 512

${ }^{3}$ Rose Dowset, "Evangelism, Service and Sosial Action in The Misional Understanding of the Cape Town Comitment, Norwegian Journal of Misiology 4( 2017), 44-53
} 
Missiology for Contemporary World ${ }^{4}$ Penelitian lain juga pernah dilakukan dengan topik yang hampir sama yaitu menyangkut missi sebagai rekonsiliasi namun tidak dalam paradigma misi Trinitarian Inkarnasional yang ditulis oleh Van de Beek. ${ }^{5}$ Penelitian lain yang pernah dipublikasikan menyangkut Missio Dei ialah Missio Dei sebagai peziarahan yang ditulis oleh Nelman Asrianus Weny, namun memiliki persepktif yang berbeda yaitu peziarahan. ${ }^{6}$ Penelitian ini bertujuan untuk mengungkapkan bahwa konsep Rekonsiliasi merupakan salah paradigma misi Trinitarian dan Inkarnasional ini dapat dipakai dalam merajut perdamaian atau rekonsiliasi di tengah konflik yang banyak terjadi di berbagai wilayah Indonesia.

\section{METODE}

Metode penelitian yang digunakan ialah penelitian kualitatif deskriptif non-eksperimental, dengan pendekatan research literature terhadap teks-teks tentang misi, baik dalam bentuk buku-buku bertopik misi, maupun jurnal misi yang terkait. Melalui penelitian yang bersifat reseacrh literature ditemukan pembahasan mengenai missio Dei dan akan digunakan untuk melihat bahwa Missio Dei sebagai rekonsiliasi dan konstruksi misi tersebut di ruang public.

\section{HASIL DAN PEMBAHASAN}

\section{Misi sebagai Partisipasi dalam Trinitas}

Secara teologis Misi Allah tidak akan pernah berubah karena berangkat dari hakekat Allah yang memang tidak pernah berubah. Gereja sebagai agen misi Allah harus sadar akan hakekat dari Misi Allah tersebut. Misi berasal dari kata Missio yang berarti mengutus atau perutusan, seperti yang telah dikatakan bahwa Misi berangkat dari Allah sendiri atau yang biasa dikenal sebagai Missio Dei tersebut merupakan misi yang berangkat dari diri Allah yang maha Trinitas tersebut yang dikenal dalam diri Bapa, Putra, dan Roh Kudus. Ketiga pribadi dalam Trinitas merupakan pribadi yang saling memiliki keterkaitan dan harmonis satu sama lain. Gerak dari Allah Trinitas ini adalah gerak kasih yang selalu terlihat dari hubungan antara ketiga pribadi tersebut. Gerak kasih ini disebut sebagai gerakan perichoresis, yang berarti gerakan saling mengisi dan memberi ruang di antara ketiga pribadi tersebut, di mana ketiga pribadi tersebut tidak terpisah dan bersatu namun tidak tercampur baur. ${ }^{7}$ Gerakan perichoresis yang dilakukan oleh tiap pribadi Allah Trinitas tersebut bersifat kasih dan selalu menginginkan pribadi lain untuk masuk dalam lingkaran kasih Allah Tritunggal tersebut. Lingkaran kasih tersebut merupakan lingkaran kasih sempurna yang tercurah bagi mahluk lain yaitu manusia. Pribadi manusia tersebut diciptakan oleh Allah Trinitas dalam fitrahnya sebagai gambar dan rupa Allah agar menikmati lingkaran kasih

\footnotetext{
${ }^{4}$ David Thang Moe, “Themes and Methodologies in Pauline Mssiologu for a Contemporary World, Journal of Missionalia (2014; 45): 99-116

${ }^{5}$ A. Van de Beek, "Mission as Reconciliation”, Journal Acta Theologica, (2019; 28): 16-33

${ }^{6}$ Nelman Asrianus Weny, "Missio Dei sebagai Ziarah Persahabatan: Menuju Sebuah Paradigma Misi Trinitarian Inkarnasional di Indonesia, Jurnal Teologi Indonesia, (2018: 2): 55-78

${ }^{7}$ Istilah perichoresis ini pertama kali dipopulerkan oleh Gregorius Nazianus seorang Bapa Gereja yang hidup di abad ke-4 di sekitar daerah Kapadokia (Turki) sekarang, lih. Joas Adiprasetya, An Imaginative Glimpse: The Trinity and Multiple Religoius Perticipations (Oregon: Pickwick Publications, 2013)
} 
tersebut. Manusia diundang dalam persekutuan Allah Trinitaris hanya dapat dilaksanakan di dalam dan melalui diri Yesus Kristus melalui teosis.

Misi Allah Trinititas yang mengundang pribadi lain di luar keberadaan dirinya inilah yang menjadi dasar atau basis misi yang diejawantahkan dalam karya dan penyelamatan sang Firman. Oleh karena itu Misi merupakan bagian tak terpisahkan dari hakikat diri Allah Tritunggal tersebut. Misi Allah Trinitas kembali dinyatakan dalam Inkarnasi di mana Sang Firman mengambil keutuhan kemanusian dan memasukkan dalam dirinya yang dikenal dalam diri Yesus Kristus, di mana Ia dalam karya dan perbuatannya menyatakan dan mengabarkan kabar baik dan keselamatan tersebut, melalui peristiwa kematian, kebangkitan, kenaikan, serta kedatangannya kembali dalam rangkaian panjang demi manusia agar dapat dipersatukan kembali dengan Allah Trinitas. Oleh karena itu misi sendiri pada hakikatnya adalah peristiwa Trinitas dan inkarnasional dalam diri Sang Sabda. Oleh sebab itu, misi tidak bisa dilepaskan dari dua hal tersebut.

\section{Misi dalam Pemahaman teologi Inkarnasi}

Pendekatan inkarnasional dalam misi Kristen telah lama menjadi bagian pembahasan filosofis misi Kristen. Peristiwa inkarnasi merupakan jantung utama iman Kristiani, dan darinya semua gerak laku Kristiani memiliki arti yang khas. Inkarnasi sendiri merupakan peristiwa di mana sabda Allah mengambil kemanusiaan seutuhnya, dan hadir dalam ruang hidup manusia serta berkarya demi pendamaian umat manusia yang telah jatuh dalam dosa sehingga memungkinkan manusia berekonsiliasi kembali dengan pribadi Allah Tritunggal tersebut.

Misi sendiri yang bermakna mission yang berarti "mengutus" lantas memiliki makna inkarnasi karena, Allah dalam Kristus hadir sebagai utusan Allah di dalam kuasa Roh Kudus untuk memperbaharui dunia, dan merekonstruksi dan merekonsiliasi kembali ciptaan agar dapat bersekutu kembali dalam persekutuan Allah Tritunggal tersebut. Oleh sebab itu misi dan praktiknya tidak dapat dilepaskan dari hakikat inkarnasi itu sendiri. Atau, dengan kata lain, inkarnasi yan merupakan pergerakan Allah keluar dari dalam diriNya, mengambil substansi daging dari seluruh ciptaanNya sejak permulaan zaman yang dikenal dalam diri Yesus Kristus merupakan kerangka kerja tertinggi bagi misi Kristen di dunia.

Menurut Ross Langmead, seorang Misiolog perempuan amerika mendekripsikan lima implikasi praktis dari misi inkarnasional ${ }^{8}$ yaitu: Pertama, misi inkarnasional adalah sebuah realitas iman yang mengekspresikan dirinya di dalam relasi-relasi transformatif; Kedua, misi inkarnasional merupakan misi di dalam komunitas yang mempraktikkan pengampunan dan merengkuh yang termarginalkan; Ketiga, pusat bagi misi inkarnasional adalah sebuah keterlibatan penuh kasih sayang, profetis, dialogis, dan penuh resiko seperti yang dilakukan oleh Yesus; Keempat, misi inkarnasional itu tidak sekedar gaya misioner atau konsep misiologis tetapi cara mengartikulasikan kehadiran dan maksud Allah bagi umat Allah dalam konteks keseharian yang beragam; Kelima, misi inkarnasional adalah undangan Allah bagi seluruh ciptaan untuk mengambil bagian dalam persahabatan yang terbuka. Dari kerangka praktis yang disebutkan oleh Langmead tersebut, maka terlihat secara jelas bahwa Misi

\footnotetext{
${ }^{8}$ Rose Langmead, “The Word Made Flesh: Towards an Incarnatonal Missiology, Dissertation, (University Press of America, 2002), 15-23, 269
} 
inkarnasional adalah misi yang bersifat misi yang rekonsiliatif, transformative yang mengahncurkan sekat-sekat marginalitas ciptaan dan kemanusiaan.

Aspek inkarnasional dalam missio Dei sebagai mission trinitaris tidak hanya memahami misi sebagai tugas sebagaimana yang dikatakan para misiolog, tetapi juga misi merupakan masalah relasi. Oleh sebab itu, "inkarnasi" sebagai titik tolak, maka "rekonsiliasi" sebagai metafora bagi keselamatan, maka hal ini menantang gereja sebagai institusi dan para misiolog untuk memperluas missio Dei kepada ranah praksis: keselamatan Allah sebagai cinta kasih sejati dalam relasi yang aktual. Puncak pelayanan misi adalah rekonsiliasi dan persahabatan yang melintasi batas-batas kelas, pendudikan, agama, gender, dan budaya yang membentuk masyarakat yang berkeadilan, selaiknya sifat inkarnasi yang mengosongkan (kenosis) menjadi sebuah kekuatan baru yang menghancurkan tembok atau sekat antar manusia, merestorasi manusia sebagai sahabat di dalam perbedaan alam relasi yang menghidupi dan menopang.

\section{Rekonsiliasi sebagai Missio Dei}

Istilah rekonsiliasi tidak dapat ditemukan baik dalam Perjanjian Lama dan Perjanjian Baru, di dalam bahasa Inggris kata reconciliation diterjemahkan sebagai perdamaian. Dalam Perjanjian Baru kata tersebut tercatat digunakan oleh Paulus yaitu dalam Roma 5: 10; 1 Korintus 7:11; dan 2 Korintus 5:18, 19, 20. Kata yang dipakai dalam teks tersebut ialah katallaso; di samping itu Paulus juga menggunakan kauta kerja apokatallaso, sebanyak tiga kali, yaitu Efesus 2:16; Kolose 1:20, 22. Istilah katalaso atau rekonsiliasi ini dipakai oleh Paulus untuk mengintrepretasikan peristiwa Kristus yang mendamaikan antara Allah dan manusia, namun disamping itu istilah yang dipakai oleh Paulus ini juga untuk meihat bahwa fenomena umum saat itu baik perseteruan, pertentangan, dan keterasingan, merupakan masalah yang krusial di jemaat tersebut. Paulus mengingkan bahwa pendamaiain dari pihak Allah menjadi cermin perdamaian antara jemaat Korintus, maupun rekonsiliasi antara hubungan orang-orang Yahudi dan Yunani. Istilah katallaso (mendamaikan, merekonsiliasi) banyak dipakai dalam kesusasteraan Yunani, pemakaian kata tersebut selalu mengandung arti yang menunjuk kepada pemulihan hubungan. Pemulihan yang dibutuhkan setelah sementara waktu kedua belah pihak berada dalam suasana berseteru, dan saling membenci satu sama lain. ${ }^{9}$ sebaliknya dalam Perjanjian Baru istilah rekonsiliasi umumnya justru menunjukkan makan teologis, yaitu pemulihan hubungan antara manusia dan Allah.

Berangkat dari beberapa definisi teologis di atas terlihat bahwa rekonsiliasi merupakan istilah umum yang dipakai dalam arti perdamaian di antara pihak yang berselisih. Walaupun berbeda secara teologis, istilah ini dipakai untuk menunjuk bagaimana Allah merekonsiliasi dirinya kepada manusia ciptaannya yang telah jatuh dalam dosa. Hal ini dimulai dari inisiatif rekonsiliasi yang terletak di tangan Allah. 2 Korintus 5:18 menyatakan bahwa "semuanya berasal dari Allah yang telah mendamaikan manusia dengan diriNya. Terlihat dengan jelas bahwa rekonsiliasi dimulai dari Allah sendiri, manusia tidak mampu berekonsiliasi dengan Allah karena sifat berdosa yang telah menjadi bagian yang tak terpisahkan dengan eksistensi manusia. Oleh karena itu manusia yang sedang dalam belenggu dosa, dan terancam murka

\footnotetext{
${ }^{9}$ H.G. link \& C. Brown, Greek Lexicon of The New Testament (Edinburg: T \& T Clarcl, 1989), 384-
} 
Allah, dalam dirinya Allah memiliki kehendak yang bebas baik untuk mendamaikan atau tidak, tetapi kenyataannya terlihat bahwa Allah mengambil inisiatif perdamaian. Hal ini dilakukan oleh Allah bukan karena manusia memintanya, tetapi semata-mata didasarkan atas kasihNya yang kekal, dalam hal ini tidak ada yang dapat dibuat oleh manusia kecuali menjadi objek pendamaian. Tentunya inisiatif Allah ini tidak akan memiliki efek jika manusia tidak merespons dengan iman, maka walaupun terlihat bahwa inisiatif pendamaian atau rekonsiliasi adalah berasal dari Allah, namun respons manusia merupakan sebuah hal yang urgen supaya karya rekonsiliasi tersebut bisa dirasakan. Hal ini nyata bahwa rekonsiliasi tersebut selalu bersifat dua arah. Allah yang empunya inisiatif rekonsiliasi tersebut tentunya harus memiliki sarana atau tindakan konkret, di mana rekonsiliasi tersebut dinyatakan dalam diri Kristus(en christo). Kristus, yang merupakan firman Allah merupakan eksekutor perdamaian. Proses rekonsiliasi tersebut dinyatakan melalui peristiwa inkarnasi yaitu firman Allah menjadi daging dan berkorban untuk keselamatan manusia sebagai bentuk final dari rekonsiliasi tersebut. Yang perlu diingat ialah sasaran perdamaian datau rekonsiliasi tersebut tidak hanya bersifat antropologis, tetapi memiliki dimensi kosmis, di mana pendamaian tersebut berakibat tidak hanya pada hubungan manusia dengan Allah saja, tetapi juga dengan alam semesta ini. ${ }^{10}$

Terlihat bahwa rekonsiliasi yang dilakukan oleh Kristus juga bersifat kosmik, yang berpengaruh pada semesta, dan di dalamnya adalah hubungan antar manusia. Oleh karena itu terdapat benang merah yang saling terkait di mana misi Allah, yaitu missio Dei yang bersifat trinitarian tersebut selalu menginginkan bahwa ada pihak lain, yaitu manusia yang ikut merasakan kasih Allah yang harmonis tersebut. Atau, dengan kata lain, Allah selalu berkerinduan untuk melihat seluruh ciptaan hidup dalam relasi perikoresis dengan dirinya. Relasi perikoresis tersebut terlihat dalam peristiwa inkarnasi sang Firman dalam bentuk daging dan dikenal dengan Yesus Kristus yang merekonsiliasi antara Allah dan manusia. Selanjutnya, jika dikaitkan dengan aspek inkarnasional, maka misi inkarnasional tersebut mengusahakan dan mengekspresikan dirinya di dalam relasi-relasi transformatif, dan merupakan misi di dalam komunitas yang mempraktikkan pengampunan dan merengkuh yang termarginalkan. Di sinilah letak misio Dei sebagai rekonsiliasi yang berlandas pada paradigma Trinitarian-inkarnasional tersebut.

\section{Rekonsiliasi: konstruksi Mission Dei dalam Konteks Ruang Publik}

Wajah Indonesia yang sekian lama terlihat damai dan aman seketika terkoyak karena konflik-konflik yang terjadi di berbagai daerah. Konflik tersebut dilatarbelakangi oleh berbagai hal, sperti SARA(suku, agama, ras, dan antargolongan). Tidak terhitung sudah berapa banyak jiwa melayang akibat konflik tersebut, tak terhitung juga berapa biaya yang dikeluarkan pemerintah untuk menyelesaikan konflik tersebut. Ada berbagai contoh konflik yang dilatarbelakangi oleh SARA, misalnya konflik Ambon, Poso, dan Sambas. Konflik tersebut juga tidak hanya memakan korban fisik tetapi mengakibatkan trauma yang begitu mendalam bagi para penyintas konflik. Ingatan tentang konflik, luka, ketakutan tidak akan bisa hilang dari ingatan mereka. Tentunya, luka tersebut jika tidak disembuhkan akan berpengaruh negative terhadap keberadaan psikis para penyintas konflik tersebut.

\footnotetext{
${ }^{10}$ A. Flitzmyer, Reconciliation in Pauline Theology, Misoula, 1971, pp. 162
} 
Kekristenan memiliki peran sentral dalam penyelesaian konflik konflik yang berlatarbelakang SARA tersebut. Pendekatan yang dapat dipakai ialah pendekatan misi, kenapa demikian? Karena misi selama ini dianggap menjadi sumber konflik antar Kekristenan dan agama lain. Oleh karena itu, misi perlu direkonstruksi untuk menemukan paradigma baru demi terwujudnya perdamaian atau rekonsiliasi dari konflik-konflik SARA tersebut.

Missio Dei sebagai misi Allah juga memiliki tugas untuk mengejawantahkan misi rekonsiliasi tersebut pada ruang publik. Selama ini diketahui bahwa ruang publik, khususnya masyarakat Indonesia disibukkan dengan konflik-konflik yang cukup menyita perhatian misalnya konflik antar agama, ataupun konflik dalam diri batin manusia antara hati dan nalar manusia sehingga membuat manusia kesulitan untuk melakukan rekonsiliasi. Konflik tersebut setidaknya menyisakan bekas luka dan trauma yang harus disembuhkan. Oleh karena itu perlu rekonsiliasi untuk menyembuhkan bekas-bekas luka dan trauma akibat konflik-konflik tersebut.

Adapun proses rekonsiliasi tersebut terdiri dari beberapa langkah yaitu: pertama, hubungan terbuka; kedua, luka; ketiga, penarikan diri; keempat, kesadaran diri; kelima, komitmen rekonsiliasi; keenam, tindakan berisiko. Keenam proses ini dinamai sebagai lingkaran rekonsiliasi. Lingkaran ini menggambarkan bahwa setiap proses akan terhubung satu sama lain, dan lingkaran ini juga merupakan model konstruktif Misi Allah sebagai rekonsiliasi yang berparadigma Trinitarian-inkarnasional. Paradigma tersebut menjiwai setiap lingkaran rekonsiliasi tersebut, sehingga dapat terlihat bahwa misi tidak hanya sekadar berbicara masalah converting keyakinan, tetapi sampai pada isu-isu di ruang publik.

Adapun model konstruktif lingkaran rekonsiliasi tersebut adalah sebagai berikut:

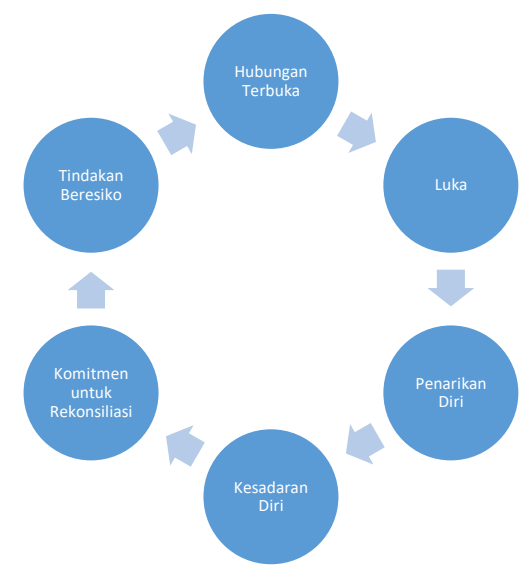

\section{Gambar 1: Lingkaran Rekonsiliasi}

Adapun proses rekonsiliasi tersebut terlihat dalam lingkaran rekonsiliasi dalam bentuk di atas. Lingkaran ini bersifat terkait satu sama lain dalam membentuk rangkaian rekonsiliasi. ${ }^{11}$

${ }^{11}$ Ide lingkaran rekonsiliasi ini diambil dari Ron Kraybill, mediation and facilitation Training Manual: Foundations and Skills for constructive Conflik Transformation (PA: Menonite Conciliation Service, 2001), 31-33 


\section{Hubungan Terbuka}

Hubungan antar manusia selalu didasarkan pada pihak yang berhubungan untuk mengambil resiko dan ada hakikatnya adalah sebuah hubungan terbuka. Dinamakan hubungan terbuka karena manusia tidak tahu persis dengan jalinan hubungan bersama dengan pihak/pribadi/ kelompok tersebut. Manusia juga tidak dapat meramalkan apakah melalui hubungan tersebut mendapat kebahagian atau luka yang membuat manusia menjadi menderita. Hal inilah yang disebut dengan risiko di mana kita tidak dapat menjalin hubungan dengan siapapun tanpa mengambil resiko di dalamnya. Melalui hubungan terbuka ini manusia diundang untuk tetap melaksanakan komunikasi dan relasi satu sama lain. Relasi dalam hubungan terbuka ini bersifat friending atau menyabahati semua orang tanpa terganggu dengan asal usul ataupun latar belakang pribadi yang didalamnya manusia berhubungan.

\section{Luka}

Hubungan antar pribadi/kelompok tersebut senantiasa merupakan hubungan yang terbuka dan mengandung resiko, maka cepat atau lambat akan terjadi konflik yang menyebabkan luka. Definisi tentang luka ialah trauma yang mengendap di dalam diri manusia yang harus disembuhkan maka jika tidak luka tersebut akan menjadi hantu dan terus-menerus menghantui pribadi/kelompok yang berkonflik tersebut. salah satu hal yang harus diingat bahwa meminimalisir luka bukanlah tindakan yang tepat tetapi bagaimana cara mengatasi dan menyembuhkan luka tersebut.

\section{Penarikan Diri}

Luka yang terjadi dalam hubungan dengan seseorang dengan orang lain akan menimbulkan tindakan yang otomatis yaitu menarik diri. Penarikan diri ini biasanya berbentuk dalam tindakan fisik maupun secara emosional. Orang yang menarik diri tersebut lambat laun secara alamiah menyadari penarikan diri bukanlah jalan terbaik sehingga hal ini memunculkan kesadaran diri pasca konflik

\section{Kesadaran Diri}

Ketika pribadi/kelompok tersebut terlibat dalam konflik dan menarik diri karena perasaan luka, biasanya di dalam diri mereka berkembang kesadaran diri yang baru. Kesadaran diri berbentuk dalam kesadaran bahwa mereka adalah mahluk yang terancam dan rapuh, rentan dan bisa terluka. Mereka tidak setangguh sebelum konflik. Oleh sebab itu upaya yang sangat krusial dalam rekonsiliasi ialah menyadarkan setiap pribadi yang berkonflik untuk menanggalkan topeng "kekuatan” dan menyadari kerapuhan mereka.

\section{Komitmen untuk Rekonsiliasi}

Keberanian dalam mengakui perasaan rapuh, terluka serta membiarkan orang lain mengetahuinya. Maka pihak-pihak yang memiliki konflik bisa bergerak maju untuk mewujudkan rekonsiliasi. Artinya, di sini kesadaran diri yang penting tentang kerapuhan dan luka tersebut justru akan melahirkan sebuah rekonsiliasi. Penyadaran diri sendiri tersebut tidak bersifat sekonyong-konyong, tanpa proses yang panjang. Perubahan tersebut memiliki waktu yang cukup panjang. Permasalahan utama yang harus disadari disini ialah membangkitkan kepercayan diri sendiri kepada orang lain setelah konflik dan luka yang dialami. Rekonsiliasi ini perlu disadari bahwa hal ini tidak akan pernah terwujud jika tidak ada pengampunan, karena 
pengampunan adalah kebijakan yang memungkinkan praktek rekonsiliasi. ${ }^{12}$ Ada beberapa elemen penting dalam rekonsiliasi atau pendamaian yaitu: penilaian moral, penolakan upaya balas dendam, empati, rekonsiliasi dan restorasi hubungan yang rusak. ${ }^{13} \mathrm{Hal}$-hal inilah yang dilakukan dalam proses atau tindakan rekonsiliasi.

\section{Tindakan Beresiko}

Setelah komitmen rekonsiliasi lahir dalam pihak yang terlibat dalam konflik, maka tahap terakhir adalah lahirnya kembali kesediaan untuk mengambil tindakan yang berisiko, di sini pihak yang terlibat dalam konflik memutuskan untuk kembali menjalin hubungan terbuka antara satu yang lain. Sebagaimana awalnya, mereka tidak tahu apa yang akan terjadi dalam hubungan mereka, maka saat ini pun mereka tidak tahu bagaimana masa depan hubungan yang dijalin apakah akan mendatangkan kebaikan atau penderitaan. Hal ini disebut dengan risky doing, di mana hal ini harus diambil oleh setiap orang yang telah berekonsiliasi.

\section{Praktik Misi Rekonsiliasi pada Ruang Publik}

Konflik komunal antaragama yang telah menelan banyak korban jiwa, tentunya memerlukan penyelesaian yang tidak hanya sekadar di permukaan, melainkan juga harus sampai pada akar rumput. Misi rekonsiliasi ini juga harus dilakukan oleh gereja/orang percaya sebagai agen rekonsiliasi. Gereja tidak boleh hanya sekedar berdoa agar lepas dari konflik, tetapi juga harus sampai pada praktik nyata atas kehidupan sehari-hari. Gereja harus peka dengan keberadaan dirinya di tengah masyarakat yang sedang berkonflik, bukan untuk memihak, tetapi mengusahakan jalan pendamaian. Usaha tersebut dapat dilakukan melalui programprogram gereja seperti hadir dalam bentuk pendampingan pastoral dan konseling terhadap pihak yang berkonflik. Selanjutnya mengusahakan rekonsiliasi melalui hal-hal yang bersifat estetik dan budaya. Hal ini menjadi sebuah usaha yang paling soft, karena setiap masyarakat terbentuk oleh karena budaya, yang didalamnya juga terdapat adat-istiadat dan kebiasaan yang telah dihidupi sejak lama.

Proses misi rekonsiliasi di ruang publik juga dapat dilaksanakan oleh gereja melalui program-program gereja yang mengusung perdamaian dan rekonsiliasi. Gereja juga harus menyadarkan para anggotanya yang sedang mengalami konflik agar mereka memahami diri mereka yang sedang sakit, mengobati trauma yang sedang dirasakan dan mengurangi prasangka-prasangka terhadap kelompok lain. Pola ini dibuat agar semua pihak yang terlibat dalam konflik dapat keluar dari tempurung agama, atau kelompok dan melihat bahwa dunia di luar tempurung jauh lebih indah dan beragam. Pola program gereja ini meluruhkan batas pemisah yang perbah tercipta akibat konflik dan membuka ruang-ruang untuk perjumpaan yang menghasilkan pemahaman baru serta konfirmasi negative selama ini dapat diluruskan. Selain itu, gereja sebagai agen misi rekonsiliasi memberikan pemahaman kepada pihak yang berkonflik bahwa musuh bersama bukanlah teman beda agama atau kelompok, melainkan fanatisme agama yang sempit, diskriminasi, perlakuan tidak adil, dan lain sebagainya 1966), 125

${ }^{12}$ David Augsburger, Helping People Forgive (Louisvilee, Kentucky: Westminster/Jhon Knox Press,

${ }^{13}$ Donald W. Shriver, Jr., An Ethics For Enemies: Forgiveness in Politics (Oxford: Oxford University Press, 1995), 128 


\section{KESIMPULAN}

Konsep Missio Dei sebagai rekonsiliasi dalam perspektif Trinitarian-inkarnasional merupakan misi Allah yang dilakukan oleh Allah Tritunggal, yang berinkarnasi dalam diri Yesus dalam kerangka kerja rekonsiliasi atau pendamaian antara Allah dan manusia; prinsip ini secara imaginatif dapat dikonstruksikan dalam peristiwa konflik antara umat manusia demi melahirkan rekonsiliasi. Perdamaian atau rekonsiliasi tersebut dapat terlihat dalam proses atau lingkaran rekonsiliasi yang dapat menjadi salah satu proses bagi perdamaian bagi pihakpihak yang memiliki konflik. Adapun lingkaran rekonsiliasi ini dimulai dari hubungan terbuka yang pada akhirnya melahirkan luka dan direspons dengan penarikan diri, dan kemudian setiap pribadi/kelompok yang terluka menyadari diri dan berwujud dalam komitmen untuk rekonsiliasi dan berakhir kepada keterbukaan dan tindakan yang tetap beresiko dalam hubungan antara pribadi/kelompok di ruang publik. Akhirnya, misi rekonsiliasi ini merupakan misi yang dapat diejawantahkan dalam ruang publik dalam konteks saat ini.

\section{REFERENSI}

Adiprasetya, Joas, An Imaginative Glimpse: The Trinity and Multiple Religoius Perticipations, Oregon: Pickwick Publications, 2013

Augsburger, David, Helping People Forgive, Louisvilee, Kentucky: Westminster/Jhon Knox Press, 1966

Beek, A. Van de, "Mission as Reconciliation", Journal Acta Theologica, $(2019 ; 28)$

Bosch, David J., Transforming Mission: Paradigm Shift in Theology of Mission, Maryknoll: Orbis, 1991

Dowset, Rose, "Evangelism, Service and Sosial Action in The Misional Understanding of the Cape Town Comitment, Norwegian Journal of Misiology 4( 2017)

Flitzmyer, A, Reconciliation in Pauline Theology, Misoula, 1971

Kraybill, Ron, mediation and facilitation Training Manual: Foundations and Skills for constructive Conflik Transformation, PA: Menonite Conciliation Service, 2001

Kuiper, Arie de, Missiologia, Jakarta: BPK Gunung Mulia, 1996

Langmead, Rose, “The Word Made Flesh: Towards an Incarnatonal Missiology, Dissertation, University Press of America, 2002

Link H.G. \& C. Brown, Greek Lexicon of The New Testament, Edinburg: T \& T Clarcl, 1989

Moe, David Thang, "Themes and Methodologies in Pauline Mssiologu for a Contemporary World, Journal of Missionalia (2014; 45)

Shriver, Donald W., Jr., An Ethics For Enemies: Forgiveness in Politics, Oxford: Oxford University Press, 1995

Weny, Nelman Asrianus, "Missio Dei sebagai Ziarah Persahabatan: Menuju Sebuah Paradigma Misi Trinitarian Inkarnasional di Indonesia, Jurnal Teologi Indonesia, (2018: 2) 